\title{
Is there a direct role for erythrocytes in the immune response?
}

\author{
Davinia Morera and Simon A MacKenzie
}

\begin{abstract}
Erythrocytes are highly abundant circulating cells in the vertebrates, which, with the notable exception of mammals, remain nucleated throughout the entire life cycle. The major function associated with these cells is respiratory gas exchange however other functions including interaction with the immune system have been attributed to these cells. Many viral, prokaryotic and eukaryotic pathogens directly target this cell type and across the vertebrate group a significant number of related pathologies have been reported. Across the primary literature mechanisms of interaction, invasion and replication between viruses and erythrocytes have been well described however the functional response of the erythrocyte has been poorly studied. A fragmented series of reports spanning the vertebrates suggests that these cells are capable of functional responses to viral infection. In contrast, in-depth proteomic studies using human erythrocytes have strongly progressed throughout the past decade providing a rich source of information related to protein expression and potential function. Furthermore information at the gene expression level is becoming available. Here we provide a review of erythrocyte-pathogen interactions, erythrocyte functions in immunity and propose in light of recent -omics research that the nucleated erythrocytes may have a direct role in the immune response.
\end{abstract}

\section{Table of contents}

1. Introduction

2. Erythrocyte-pathogen interaction

3. Immunity

4. Insights from genomic and proteomic studies

5. Future directions

6. Competing interests

7. Authors' contributions

8. Acknowledgements

9. References

\section{Introduction}

In all vertebrates, blood is composed of cells and plasma protein (90\% in volume is water). By far the most abundant cell type in circulation is the erythrocyte, present in the nucleated form in the majority of vertebrates with the notable exception of the mammals. All vertebrates also have distinct populations of circulating leukocytes and non-mammalian vertebrates have nucleated thrombocytes instead of platelets. Erythrocytes are generally characterized as oval in shape and their characteristic

* Correspondence: Simon.Mackenzie@uab.es

Institute of Biotechnology and Biomedicine, Universitat Autònoma de Barcelona, 08193 Barcelona, Spain red color is due to the respiratory globin pigments including the hemoglobins, the most abundant protein in these cells. All non-mammalian (birds, reptiles, amphibians and fish) erythrocytes with a few isolated exceptions are nucleated and contain organelles in their cytoplasm [1]. Erythrocyte longevity varies across the major vertebrate groups where in humans the cellular half life of erythrocytes is about 120 days and is about 40, 600-800, 300-1400 and 80-500 days in birds, reptiles, amphibians and fish respectively [1-5]. Furthermore and with a direct relationship to longevity, different maturation states are observed in the circulating erythrocytes of non-mammalian species including; changes in cytoplasmatic shape, staining, nuclear size and chromatin density. Total RNA and organelles content follow an inverse relationship with cellular age where young red blood cells contain a higher total concentration of RNA and aging cells display a loss of cellular organelles including ribosomes and mitochondria [6]. Interestingly, in endothermic species cellular longevity is similar indicative of a parallel evolutionary trend toward respiratory specialization linked in parallel to increased metabolic demand. However in view of the vast diversity of vertebrate species where the ectotherms are in the majority, 
the fish alone represent $>28000$ species, and the scarcity of such studies this proposed linkage warrants further investigation. Erythrocyte numbers in blood of vertebrates range from 1 to $5 \times 10^{6} / \mathrm{mm}^{3}$ and follow a descending evolutionary scale where the fish have the lowest cell counts [1,7]. This relationship can be further expanded including metabolic activity where highly active fish species, for example tuna, have higher numbers of circulating erythrocytes and show facultative endothermy [8]. Thus within the vertebrate group the erythrocytes appear to have significant differences in terms of circulating numbers and longevity which may reflect the metabolic needs of the species. However such a sweeping statement will clearly requires an empirical approach as the majority of these observations are derived from a small and likely non-representative set of vertebrate species.

Hematopoiesis is defined as blood cell formation from multi-potent stem cells that are characterized by selfrenewal and the potential to differentiate into a mature set of distinct cellular phenotypes. Hematopoiesis has been shown to maintain a set of conserved molecular pathways based upon a conserved group of hematopoietic transcription factors present from humans to fish $[9,10]$. Erythropoiesis and myelopoiesis share cellular precursors and the production of erythrocytes or myeloid cells is dependent upon the key transcription factors Gata1 and PU.1 [11]. The regulation of these two transcription factors in the zebrafish embryo is a critical step in myelo-erythroid lineage commitment where Gata1 is required for erythroid cell differentiation and PU.1 for myelopoiesis [11-13]. Thus the molecular mechanisms underpinning hematopoiesis in fish and mammals appear to be remarkably conserved [14].

The principal function associated to the erythrocytes is oxygen and carbon dioxide transport. In addition to this gas exchange function, they also play a role in homeostasis protecting against oxidative damage and regulating blood flow distribution in skeletal muscle [15-17]. Other potential functions (Table 1) [18-44] have also been attributed to the erythrocytes for example: human erythrocytes may play a role in modulating $\mathrm{T}$ cell proliferation and survival by enhancing cytokine secretion and induction of the IL2R thus modulating CD4+/8+ ratios $[21,45,46]$. Interestingly this finding was published almost twenty years ago in sheep [47]. A fragmented series of publications can be identified across the vertebrates in which erythrocyte functions appear to be intimately connected to a range of physiological processes. These studies have shown that the cellular machinery and related biological processes are present in erythrocytes for intracellular signalling $[16,48]$, transcription [49], protein synthesis [50] and secretion [51]. Functional responses attributed include amongst others;
Table 1 Erythrocyte functions in vertebrates

\begin{tabular}{lccccc}
\hline Proposed functions & Mammals & Fish & Amphibian & Reptils & Birds \\
\hline Gas exchange function & {$[18]$} & {$[18]$} & {$[18]$} & {$[18]$} & {$[18]$} \\
Sugar transport & {$[19]$} & {$[26]$} & {$[34]$} & {$[36]$} & {$[40]$} \\
Calcium homeostasis & {$[20]$} & {$[27]$} & {$[35]$} & {$[37]$} & {$[41]$} \\
Redox homeostasis & {$[17]$} & {$[28]$} & - & {$[38]$} & {$[42]$} \\
Cell proliferation & {$[21]$} & - & - & - & {$[43]$} \\
Antiviral response & & {$[29]$} & - & - & - \\
Antimicrobial activity & & & & & \\
Immune complex & {$[22]$} & {$[30]$} & - & - & - \\
ROS production & {$[23]$} & {$[31]$} & - & - & - \\
Hemoglobin & {$[24]$} & {$[32]$} & - & {$[39]$} & - \\
Other related functions & {$[25]$} & {$[33]$} & - & - & {$[44]$} \\
\hline
\end{tabular}

Table reports functions associated to erythrocytes in mammals, fish, amphibian, reptiles and birds. References are numbered according to appearance.

hemoglobin derived anti-microbial responses [23], glycophorin A-mediated pathogen sink [52], eNOS-like protein and activity [48], specific HIV-1 binding [53], interferon-alpha mRNA induction [29], hormone binding [54] and CR1-dependent immune complex clearance [55]. Thus it would appear that diverse ranges of nonrespiratory biological processes in erythrocytes are observed across the vertebrates.

\section{Erythrocyte-pathogen interaction}

There exists a broad spectrum of parasites that specifically invade the erythrocytes of vertebrates (Table 2) [53,56-66] causing a diverse set of negative consequences and disease in the host organism. The host environment is complex where a significant number of inter-related biological factors including both physical and biological barriers such as the skin and the mucosal immune system influence the ability of pathogens to invade the host. Once a pathogen has cleared the primary barriers and accesses the circulatory system the erythrocytes may become a primary target for pathogen dispersal/transport throughout the organism. However not all parasites may induce damage within the host. For example, bacteria of the Anaplasmatacea family form inclusions in the erythrocyte cytoplasm but have not been observed to cause disease or negative health effects either in the host organisms or in host erythrocytes [4]. A significant lack of knowledge exists about many of the erythrocyte-related pathologies at the level of host-pathogen recognition and the molecular mechanisms underpinning erythrocyte responses; the major exception being the biology of the Plasmodium species where more than 200 are known and almost half of these species target the lizards [65,67-69]. The importance to human health of this particular parasite has fueled much research that has uncovered a high degree of complexity related to host specificity, underlying 
Table 2 Parasites of vertebrate erythrocytes

\begin{tabular}{|c|c|c|c|c|c|c|}
\hline Family & Genera & Mammals & Fish & Amphibia & Reptils & Birds \\
\hline Dactylosomatidae & Babesiosoma & {$[56]$} & {$[4]$} & [4] & {$[4]$} & [62] \\
\hline Dactylosomatidae & Dactylosoma & - & {$[4]$} & [4] & [4] & - \\
\hline Garniidae & Garnia & - & - & - & [4] & [63] \\
\hline Garniidae & Progarnia & - & - & - & [4] & - \\
\hline Garniidae & Saurocytozoon & - & - & - & [4] & - \\
\hline Haemogregarinidae & Cyrilia & - & {$[4]$} & - & - & - \\
\hline Haemogregarinidae & Desseria & - & {$[4]$} & - & - & - \\
\hline Haemogregarinidae & Haemogregarina & {$[57]$} & {$[4]$} & [4] & [4] & [57] \\
\hline Haemogregarinidae & Hemolivia & - & - & [4] & [4] & - \\
\hline Haemogregarinidae & Hepatozoon & {$[57]$} & {$[4]$} & [4] & [4] & {$[57]$} \\
\hline Haemogregarinidae & Karyolysus & - & - & [57] & [4] & - \\
\hline Haemoproteidae & Haemoproteus & {$[57]$} & - & [4] & [4] & [64] \\
\hline Haemoproteidae & Haemocystidium & - & - & - & [4] & - \\
\hline Haemoproteidae & Simondia & - & - & - & [4] & - \\
\hline Lankesterellidae & Lainsonia & - & - & - & [4] & - \\
\hline Lankesterellidae & Lankesterella & - & - & [4] & [4] & [57] \\
\hline Lankesterellidae & Schellackia & - & - & {$[4]$} & [4] & - \\
\hline Plasmodiidae & Billbraya & - & - & - & [4] & - \\
\hline Plasmodiidae & Mesnilium & - & {$[4]$} & - & - & - \\
\hline Plasmodiidae & Plasmodium & {$[58]$} & - & - & [4] & [65] \\
\hline Trypanosomatida & Sauroleishmania & - & - & - & [4] & - \\
\hline Uncertain & Chelonoplasma & - & - & - & [4] & - \\
\hline Uncertain & Cingula & - & - & - & [4] & - \\
\hline Uncertain & Erythrocytonucleophaga & - & - & [4] & - & - \\
\hline Uncertain & Globidiellum & - & {$[4]$} & - & - & - \\
\hline Uncertain & Haematractidium & - & {$[4]$} & - & [4] & - \\
\hline Uncertain & Haemohormidium & - & {$[4]$} & - & [4] & - \\
\hline Uncertain & Sauromella & - & - & - & [4] & - \\
\hline Unceratin & Tunetella & - & - & - & [4] & - \\
\hline Anaplasmataceae & Aegyptianella & - & - & [4] & [4] & - \\
\hline Anaplasmataceae & Bertarellia & - & - & [4] & [4] & - \\
\hline Anaplasmataceae & Cytamoeba & - & - & [4] & [4] & - \\
\hline Anaplasmataceae & Eperythrozoon & [59] & {$[4]$} & - & - & - \\
\hline Anaplasmataceae & Haemobartonella & [59] & {$[4]$} & [4] & [4] & - \\
\hline Bartonellaceae & Grahamella & - & - & - & [4] & - \\
\hline Viral & Orthomyxoviridae Influenza A & {$[60,61]$} & - & - & - & {$[66]$} \\
\hline Viral & Retroviridae Lentivirus (HIV-1) & [53] & - & - & - & - \\
\hline Viral & Orthomyxoviridae Isavirus (ISAV) & - & {$[4]$} & - & - & - \\
\hline Viral & unknown Immanoplasma* & - & {$[4]$} & - & - & - \\
\hline Viral & unknown Pirhemocyton* & - & - & [4] & [4] & - \\
\hline Viral & unknown Toddia* & - & [4] & [4] & [4] & - \\
\hline
\end{tabular}

Table reports parasitic genera infecting both nucleated and non-nucleated vertebrate erythrocytes. References are numbers according to bibliography listing. *These genus names are not accepted viral genera, but were designated in the early 1900s based on erythrocyte inclusions thought to be caused by protozoan parasites. The inclusions were subsequently found to be associated with icosahedral virus particles considered most likely to be large DNA viruses, possibly in the family Iridoviridae, but the taxonomy has not been conclusively defined. 
molecular mechanisms and host response. We will not review the malaria literature as this has been extensively covered elsewhere $[58,70]$. Instead here we will focus upon the basic knowledge that supports an active role for the nucleated erythrocytes in vertebrate immunity.

Different families of parasites invade erythrocytes both from mammals (enucleated) and non-mammals (nucleated). In 2000, Davies et al. presented an extensive list of intra-erythrocytic parasites compiled from mammals, birds, amphibian, reptiles and fishes [4]. Table 2 summarizes family and genera of parasites that infect mammalian and non-mammalian erythrocytes. Protozoan, prokaryotes and viral parasites are indicated in the table with others of uncertain taxonomic status or identity. Although birds, amphibian, reptiles and fish are all affected by different parasite genera, the reptiles have been shown to be the most highly affected group by the range of known parasites. This however may again be bias in view of the representation of the species studied and sampled. Rather than favoring infection of mammals or non-mammals, Haemohormidium and Dactylosoma are distinct in infecting the cold-blooded vertebrates; fish, reptiles and amphibians [4]. The interactions of viral particles with the host are determined by two major factors; host cell membrane proteins and the molecular determinants on the virion surface. The presence or absence of specific receptors on the cell membrane and their organization are key elements for virus invasion and the development of disease in the vertebrates. Virus-cell interaction is a central issue in animal/ human health and the development of prophylactic medicines a key element in combating viral disease [71]. In 1979, infection and de novo synthesis of the influenza virus (A/FPV/Rostoch/34 (Havl N1) proteins in nucleated erythrocytes of birds was described for the first time [66]. Following this a significant body of studies using the influenza virus genera have been published describing in great detail erythrocyte-influenza virus interaction in a range of vertebrate groups including humans where the viral hemagglutinin glycoprotein (HA) has been shown to mediate specific recognition, binding and fusion between the virus and the target cell $[60,61]$. Surprisingly the response of erythrocytes to viral infection has been poorly studied especially in the nucleated erythrocytes of the non-mammalian vertebrates.

\section{Immunity}

Nelson (1953) described erythrocytes as directly participating in the immune complex reaction (bacteria, complement and antibody) and this specific binding suggested a central role for this cell type [72]. This interaction of erythrocytes with the immune complex has been repeatedly shown (reviewed in [55]). Fish and chickens erythrocytes have been shown to actively form rosettes to facilitate the clearance of pathogens by macrophages [73], and could produce cytokines or specific signalling molecules in response to binding [44,74]. In 1999, Bishlawy et al. hypothesized a relationship between erythrocytes, hemoglobin and the immune system suggesting an active role in the immune response to pathogens [75]. A supporting argument may be found in several studies of hemoglobin function. Hemoglobin is an important source of bioactive peptides that have been shown to participate in the innate immune response $[23,24]$. The antimicrobial activity of the respiratory globins is likely one of the most ancient anti-microbial mechanisms conserved across the invertebrates and vertebrates [76]. These respiratory proteinderived peptides exhibit antimicrobial activity against Gram-positive, Gram-negative bacteria and yeast [24,77]. Although little attention has been given to these observations it remains clear that vertebrate hemoglobins and associated molecules in invertebrate species have bactericidal properties and participate in the killing of invading microbes. Glycophorin-A (GYPA) is the most abundant glycoprotein on the mammalian erythrocyte cell surface $\left(0.5-1 \times 10^{6}\right.$ copies per cell) [78] and it has been hypothesized that GYPA plays a role in pathogen recognition potentially acting as a decoy receptor in enucleated mammalian erythrocytes. Thus GYPA would bind pathogens on the erythrocyte cell surface thereby sequestering invading organisms from important tissues potentially reducing pathogen load. It has been suggested that these pathogen bound to erythrocytes would be cleared by macrophages in the spleen [52]. Supporting observations for erythrocyte specific binding of "active" viral particles was recently demonstrated for HIV-1 in human erythrocytes [53]. In both fish and chicken, specific PRRs (pathogen recognition receptors) including members of the toll-like receptors (TLRs) and peptidoglycan recognition protein (PGRP) receptor families have been shown to be expressed in erythrocytes and ligand-specific engagement induces a physiological response that is stimulus-dependent $[79,80]$. Thus an active role in pathogen recognition must be considered and leads to the hypothesis that the presence of PRRs in non-mammalian erythrocytes and an associated pathogen associated molecular pattern (PAMP)-specific response strongly points toward a direct role for nucleated erythrocytes in the immune response.

The production of type I interferon is a well-characterized immune response that bridges the innate and acquired immune responses and has been shown in most vertebrate groups $[81,82]$. Workenhe and colleagues published the first study showing that erythrocytes could play an immunological role in virus response observing that nucleated erythrocytes from Atlantic 
(a)
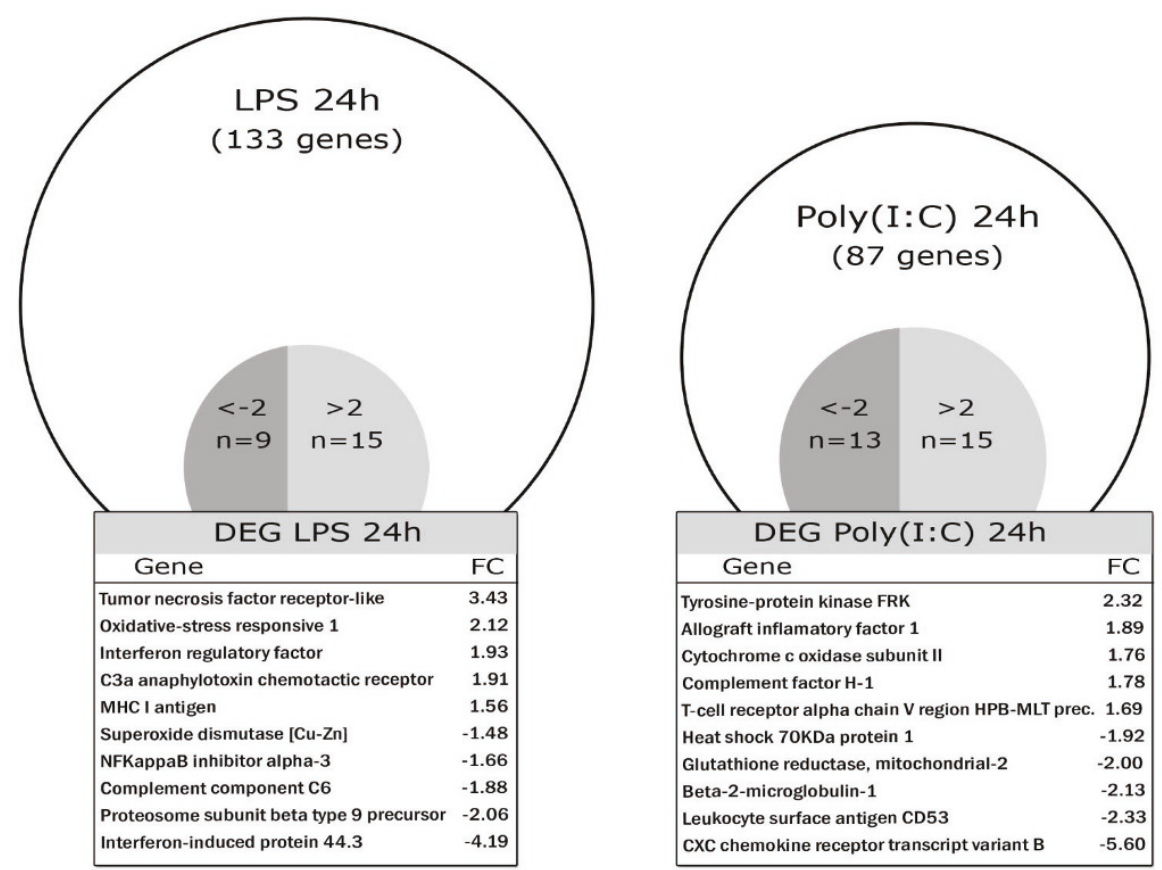

(b)
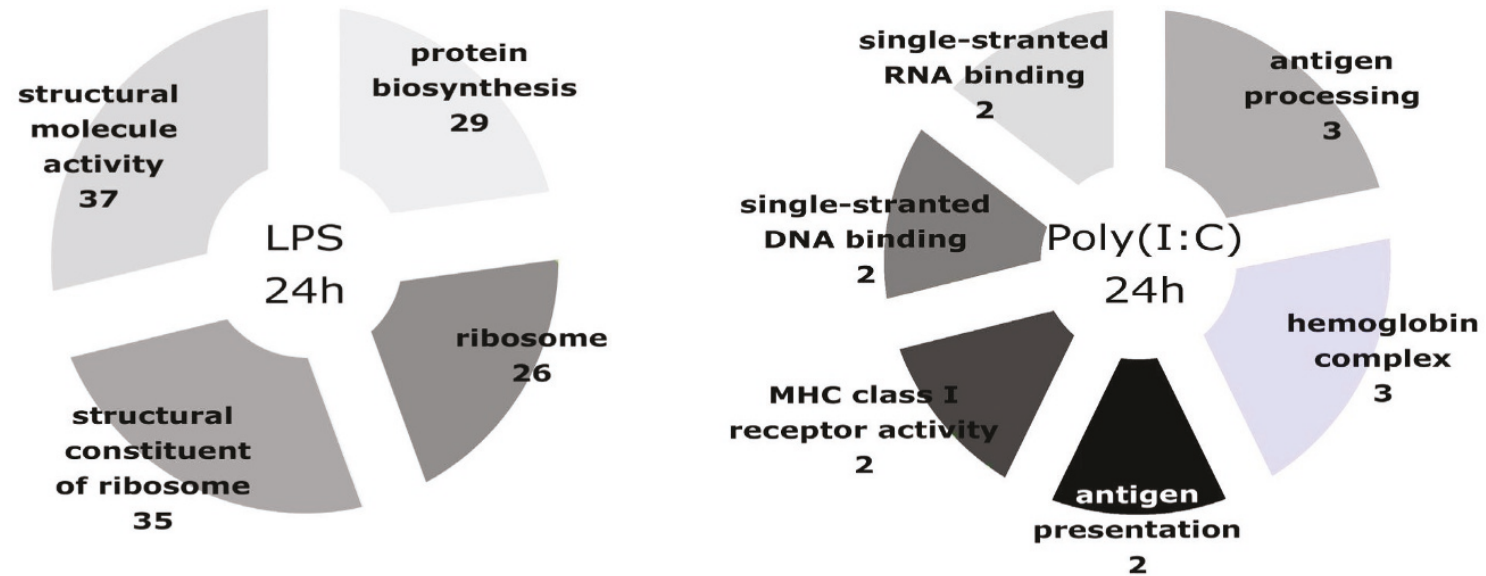

Figure 1 Microarray analysis (SFA2.0 cDNA salmonid-specific array. Accession number; GPL6154) in rainbow trout erythrocytes stimulated for $24 \mathrm{~h}$ with LPS or poly (I:C). (a) Total number of differential expressed genes (DEG) identified using a $p$-value of $<0.01$. The total number of DEG with a fold change greater than 2 (FC $>2$ ) (t-student, $p<0.01$ ) are shown and selected DEG with relevance to immunity $(p<0.01)$ are shown. Results obtained from three independent experiments for each PAMP (five animals for each experiment). (b) Over representation of Gene Ontology functional categories. Categories were selected with Yates corrected Chi squared $(p<0.05)$. The number of DEG for each overrepresented category is shown. 
salmon produced $\alpha$-interferon in response to ISAV (infectious salmon anaemia virus) infection [29] however no more studies have been reported in this field or in other species. Studies in rainbow trout and chicken erythrocytes demonstrate that the stimulation of these cells with different PAMPs regulate the synthesis of different mRNAs of immune response related genes like TLRs, CCL4 or $\alpha$-interferon [80].

\section{Insights from genomic and proteomic studies}

The emergence of high-throughput sequencing technologies both for genomic and proteomic studies has steadily been changing the molecular landscape of modern biological research. In the case of the erythrocytes, in human cells, significant advances have been made in characterizing the proteome of this enucleated cell in search of prognostic markers for disease. In 2002 a total of 102 proteins where identified by 2-D electrophoresis and MALDI-TOF analysis [83], this was rapidly followed in 2004 by the description of 181 protein sequences from the erythrocyte membrane and cytoplasm using ion trap mass spectrometry [84]. In 2005, 272 erythrocyte proteins were identified using a novel approach, 2$\mathrm{D}$ nano-high performance liquid chromatography and electrospray ionization tandem mass spectrometry (2-D nano-HPLC-ESI-MS/MS) [85]. Following this trend over the past decade a total of 1989 non-redundant human erythrocyte proteins have been identified [86]. An important observation made from these studies is that all authors agree that human erythrocytes express proteins that are related to cellular defence, the immune response and potentially multiple other biological functions. This supports the hypothesis that the erythrocytes even in the mammalian enucleated form have the potential as described by the proteome to participate in the immune response.

At the level of the transcriptome human erythrocytes have been shown (Human Genome Focus GeneChip, Affymetrix) to contain multiple mRNAs with direct relevance to biological processes including signal transduction and the immune response [87]. Recently in fish, custom cDNA microarrays (16 K cGRASP) have been used in the rainbow trout (Oncorhynchus mykiss) to explore the potential for specific erythrocyte mRNAs as prognostic markers for stress. In this study genes related to stress physiology and the immune response were shown to be the most highly regulated under a heat stress experimental regime [88]. In line with these results, analysis of isolated trout erythrocytes challenged for 24 hours with either lipopolysaccharide (LPS) or poly (I:C), a double stranded RNA analog, can identify a PAMP-specific regulation of gene expression in erythrocytes (Figure 1a). Analysis of over-representation of Gene Ontology (GO) categories
(Figure 1b) identified that LPS challenge strongly affected biological processes broadly related to protein synthesis where four differentially represented GO categories including protein biosynthesis, ribosome, structural constituent of ribosome and structural molecule activity were significantly different after challenge. Interestingly, the response to poly (I:C) was characterized as related to the immune response: GO categories related to antigen processing, antigen presentation and MHC class I receptor activity, moreover singlestranded RNA-binding, single-stranded DNA-binding and hemoglobin complex were up-regulated. These preliminary results highlight two important points; firstly, PAMP challenge induces a specific response at the level of the erythrocyte transcriptome and secondly this response is dependent upon the PAMP itself thus is likely to be PAMP-PRR specific.

\section{Future directions}

In conclusion, the increasing knowledge of parasite biology in parallel to a growing body of research effort aiming toward understanding host-pathogen interactions using the -omics technologies is opening a broad spectrum of potential avenues for investigation of vaccines for the control and prevention of disease. The contributions from both genomics and proteomics have provided significant advances toward the understanding of the vertebrate erythrocytes. Importantly across the entire vertebrate group several studies have now shown that the erythrocytes express proteins and mRNAs that are related to physiological processes that appear unrelated to the highly specialised role ascribed to these cells. Thus it may appear that an as yet unexplored series of potential functions for the erythrocytes may be present that in turn implies a more diverse physiological role for these abundant cells.

\section{Acknowledgements}

The supporting microarray data in this review was generated with the financial support of the Consolider-Ingenio Programme 2010, project CSD2007-0002 funded by the Spanish Ministry of Science and Education, Spain to SM. D.M. (FPU, AP2006-02715) is funded by the Ministerio de Ciencia e Innovación, Spain.

\section{Authors' contributions}

DM performed experimentation, analysis and drafted the manuscript. SM conceived, designed and coordinated the study. Both authors read and approved the manuscript.

\section{Competing interests}

The authors declare that they have no competing interests.

Received: 18 November 2010 Accepted: 29 July 2011

Published: 29 July 2011

\section{References}

1. Claver JA, Quaglia AIE: Comparative Morphology, Development, and Function of Blood Cells. Journal of Exotic Pet Medicine 2009, 18:87-97. 
2. Avery EH, Lee BL, Freedland RA, Cornelius CE: Bile pigments in gallbladder and freshly-secreted hepatic duct bile from fed and fasted rainbow trout, Oncorhynchus mykiss. Comparative Biochemistry and Physiology Part A: Physiology 1992, 101:857-861.

3. Bairbre OM, MRCVS MVBC: Avian anatomy and physiology. Clinical Anatomy and Physiology of Exotic Species Edinburgh: W.B. Saunders; 2005, 97-161.

4. Davies AJ, Johnston MRL: The biology of some intraerythrocytic parasites of fishes, amphibia and reptiles. In Advances in Parasitology. Volume 45. Academic Press; 2000:1-107.

5. Fischer U, Ototake M, Nakanishi T: Life span of circulating blood cells in ginbuna crucian carp (Carassius auratus langsdorfii). Fish Shellfish Immunol 1998, 8:339-349.

6. Lund SG, Phillips MC, Moyes CD, Tufts BL: The effects of cell ageing on protein synthesis in rainbow trout (Oncorhynchus mykiss) red blood cells. J Exp Biol 2000, 203:2219-2228.

7. Sherwood L: Human Physiology: From Cells to Systems Belmont: Cengage Learning; 2010.

8. Block BA, Stevens ED: Tuna: Physiology, Ecology and Evolution San Diego: Academic Press; 2001

9. Barreda DR, Belosevic M: Transcriptional regulation of hemopoiesis. Dev Comp Immunol 2001, 25:763-789.

10. Davidson AJ, Zon LI: The 'definitive' (and 'primitive') guide to zebrafish hematopoiesis. Oncogene 2004, 23:7233-7246.

11. Rhodes J, Hagen A, Hsu K, Deng M, Liu TX, Look AT, Kanki JP: Interplay of pu. 1 and gata1 determines myelo-erythroid progenitor cell fate in zebrafish. Dev Cell 2005, 8:97-108.

12. Lieschke GJ, Oates AC, Paw BH, Thompson MA, Hall NE, Ward AC, Ho RK, Zon LI, Layton JE: Zebrafish SPI-1 (PU.1) marks a site of myeloid development independent of primitive erythropoiesis: implications for axial patterning. Dev Biol 2002, 246:274-295.

13. Galloway JL, Wingert RA, Thisse C, Thisse B, Zon LI: Loss of gata1 but not gata2 converts erythropoiesis to myelopoiesis in zebrafish embryos. Dev Cell 2005, 8:109-116.

14. Evans CJ, Hartenstein V, Banerjee U: Thicker than blood: conserved mechanisms in Drosophila and vertebrate hematopoiesis. Dev Cell 2003, 5:673-690

15. Richards RS, Roberts TK, McGregor NR, Dunstan RH, Butt HL: The role of erythrocytes in the inactivation of free radicals. Med Hypotheses 1998, 50:363-367.

16. Sprague RS, Stephenson AH, Ellsworth ML: Red not dead: signaling in and from erythrocytes. Trends Endocrinol Metab 2007, 18:350-355.

17. Tsantes AE, Bonovas S, Travlou A, Sitaras NM: Redox imbalance, macrocytosis, and RBC homeostasis. Antioxid Redox Signal 2006, 8:1205-1216.

18. Nikinmaa M: Oxygen and carbon dioxide transport in vertebrate erythrocytes: an evolutionary change in the role of membrane transport. J Exp Biol 1997, 200:369-380.

19. Montel-Hagen A, Sitbon M, Taylor N: Erythroid glucose transporters. Curr Opin Hematol 2009, 16:165-172

20. Perez-Gordones MC, Lugo MR, Winkler M, Cervino V, Benaim G: Diacylglycerol regulates the plasma membrane calcium pump from human erythrocytes by direct interaction. Arch Biochem Biophys 2009, 489:55-61

21. Fonseca AM, Pereira CF, Porto G, Arosa FA: Red blood cells promote survival and cell cycle progression of human peripheral blood T cells independently of CD58/LFA-3 and heme compounds. Cell Immunol 2003, 224:17-28.

22. Gershon H: The anti-inflammatory role of the erythrocyte: impairment in the elderly. Archives of Gerontology and Geriatrics 1997, 24:157-165.

23. Jiang N, Tan NS, Ho B, Ding JL: Respiratory protein-generated reactive oxygen species as an antimicrobial strategy. Nat Immunol 2007, 8:1114-1122.

24. Liepke C, Baxmann S, Heine C, Breithaupt N, Standker L, Forssmann WG: Human hemoglobin-derived peptides exhibit antimicrobial activity: a class of host defense peptides. J Chromatogr B Analyt Technol Biomed Life Sci 2003, 791:345-356.

25. Morariu AM, Maathuis MH, Asgeirsdottir SA, Leuvenink HG, Boonstra PW, van Oeveren W, Ploeg RJ, Molema I, Rakhorst G: Acute isovolemic hemodilution triggers proinflammatory and procoagulatory endothelial activation in vital organs: role of erythrocyte aggregation. Microcirculation 2006, 13:397-409.

26. Pesquero J, Albi JL, Gallardo MA, Planas J, Sanchez J: Glucose metabolism by trout (Salmo trutta) red blood cells. J Comp Physiol B 1992, 162:448-454.

27. Orlov SN, Aksentsev SL, Kotelevtsev SV: Extracellular calcium is required for the maintenance of plasma membrane integrity in nucleated cells. Cell Calcium 2005, 38:53-57.

28. Jensen FB: The role of nitrite in nitric oxide homeostasis: A comparative perspective. Biochimica et Biophysica Acta (BBA) - Bioenergetics 2009, 1787:841-848.

29. Workenhe ST, Kibenge MJ, Wright GM, Wadowska DW, Groman DB, Kibenge FS: Infectious salmon anaemia virus replication and induction of alpha interferon in Atlantic salmon erythrocytes. Virol J 2008, 5:36.

30. Schraml B, Baker MA, Reilly BD: A complement receptor for opsonized immune complexes on erythrocytes from Oncorhynchus mykiss but not Ictalarus punctatus. Molecular Immunology 2006, 43:1595-1603.

31. Fedeli D, Carloni M, Falcioni G: Oxidative damage in trout erythrocyte in response to "in vitro" copper exposure. Mar Environ Res 2010, 69:172-177.

32. Ullal AJ, Wayne Litaker R, Noga EJ: Antimicrobial peptides derived from hemoglobin are expressed in epithelium of channel catfish (Ictalurus punctatus, Rafinesque). Developmental \& Comparative Immunology 2008, 32:1301-1312.

33. Fernandes JM, Smith VJ: Partial purification of antibacterial proteinaceous factors from erythrocytes of Oncorhynchus mykiss. Fish Shellfish Immunol 2004, 16:1-9.

34. Kaloyianni M, Doukakis I: Effect of adrenaline on glucose transport in red cells of Rana balcanica. Gen Physiol Biophys 2003, 22:69-80.

35. Light DB, Attwood AJ, Siegel C, Baumann NL: Cell swelling increases intracellular calcium in Necturus erythrocytes. J Cell Sci 2003, 116:101-109.

36. Mauro NA, Isaacks RE: Examination of Reptilian Erythrocytes as Models of the Progenitor of Mammalian Red Blood Cells. Comparative Biochemistry and Physiology Part A: Physiology 1997, 116:323-327.

37. Bagnaresi P, Rodrigues MT, Garcia CRS: Calcium signaling in lizard red blood cells. Comparative Biochemistry and Physiology - Part A: Molecular \& Integrative Physiology 2007, 147:779-787.

38. Torsoni MA, Ogo SH: Hemoglobin-sulfhydryls from tortoise (Geochelone carbonaria) can reduce oxidative damage induced by organic hydroperoxide in erythrocyte membrane. Comparative Biochemistry and Physiology Part B: Biochemistry and Molecular Biology 2000, 126:571-577.

39. Parish CA, Jiang H, Tokiwa Y, Berova N, Nakanishi K, McCabe D, Zuckerman W, Xia MM, Gabay JE: Broad-spectrum antimicrobial activity of hemoglobin. Bioorg Med Chem 2001, 9:377-382.

40. Braun EJ, Sweazea KL: Glucose regulation in birds. Comp Biochem Physiol B Biochem Mol Biol 2008, 151:1-9.

41. Alves-Ferreira M, Scofano HM, Ferreira-Pereira A: $\mathrm{Ca}(2+)$-ATPase from chicken (Gallus domesticus) erythrocyte plasma membrane: effects of calmodulin and taurine on the $\mathrm{Ca}(2+)$-dependent ATPase activity and Ca2+ uptake. Comp Biochem Physiol B Biochem Mol Biol 1999, 122:269-276.

42. Di Simplicio P, Cacace MG, Lusini L, Giannerini F, Giustarini D, Rossi R: Role of Protein -SH Groups in Redox Homeostasis- The Erythrocyte as a Model System. Archives of Biochemistry and Biophysics 1998, 355:145-152.

43. Bertram EM, Jilbert AR, Kotlarski I: Optimization of an in vitro assay which measures the proliferation of duck $T$ lymphocytes from peripheral blood in response to stimulation with PHA and ConA. Dev Comp Immunol 1997, 21:299-310.

44. Passantino L, Massaro MA, Jirillo F, Di Modugno D, Ribaud MR, Modugno GD, Passantino GF, Jirillo E: Antigenically activated avian erythrocytes release cytokine-like factors: a conserved phylogenetic function discovered in fish. Immunopharmacol Immunotoxicol 2007, 29:141-152.

45. Kalechman Y, Herman S, Gafter U, Sredni B: Enhancing effects of autologous erythrocytes on human or mouse cytokine secretion and IL2R expression. Cell Immunol 1993, 148:114-129.

46. Porto B, Fonseca AM, Godinho I, Arosa FA, Porto G: Human red blood cells have an enhancing effect on the relative expansion of CD8+ T lymphocytes in vitro. Cell Prolif 2001, 34:359-367.

47. Ebert EC: Sheep red blood cells enhance T-lymphocyte proliferation. Clin Immunol Immunopathol 1985, 37:203-212. 
48. Kleinbongard P, Schulz R, Rassaf T, Lauer T, Dejam A, Jax T, Kumara I, Gharini P, Kabanova S, Ozuyaman B, et al: Red blood cells express a functional endothelial nitric oxide synthase. Blood 2006, 107:2943-2951.

49. Yamamoto ML, Clark TA, Gee SL, Kang JA, Schweitzer AC, Wickrema A Conboy JG: Alternative pre-mRNA splicing switches modulate gene expression in late erythropoiesis. Blood 2009, 113:3363-3370.

50. Harrington DB, Becker RO: Electrical stimulation of RNA and protein synthesis in the frog erythrocyte. Experimental Cell Research 1973, 76:95-98.

51. Blishchenko EY, Mernenko OA, Yatskin ON, Ziganshin RH, Philippova MM, Karelin AA, Ivanov VT: Neokyotorphin and neokyotorphin (1-4): secretion by erythrocytes and regulation of tumor cell growth. FEBS Lett 1997, 414:125-128.

52. Baum J, Ward RH, Conway DJ: Natural selection on the erythrocyte surface. Mol Biol Evol 2002, 19:223-229.

53. Beck Z, Brown BK, Wieczorek L, Peachman KK, Matyas GR, Polonis VR, Rao M, Alving CR: Human erythrocytes selectively bind and enrich infectious HIV-1 virions. PLoS One 2009, 4:e8297.

54. Pottinger $\mathrm{T}$, Brierley II: A putative cortisol receptor in the rainbow trout erythrocyte: stress prevents starvation-induced increases in specific binding of cortisol. J Exp Biol 1997, 200:2035-2043

55. Hess C, Schifferli JA: Immune adherence revisited: novel players in an old game. News Physiol Sci 2003, 18:104-108.

56. Montero E, Rodriguez M, Oksov Y, Lobo CA: Babesia divergens apical membrane antigen 1 and its interaction with the human red blood cell. Infect Immun 2009, 77:4783-4793.

57. Cox FE: The evolutionary expansion of the Sporozoa. Int J Parasitol 1994, 24:1301-1316.

58. Miller LH, Baruch DI, Marsh K, Doumbo OK: The pathogenic basis of malaria. Nature 2002, 415:673-679.

59. Harvey JW: Erythrocytes. Atlas of Veterinary Hematology Philadelphia: W.B. Saunders; 2001, 21-44.

60. Schoch C, Blumenthal R, Clague MJ: A long-lived state for influenza viruserythrocyte complexes committed to fusion at neutral $\mathrm{pH}$. FEBS Lett 1992, 311:221-225

61. Skehel JJ, Wiley DC: Receptor binding and membrane fusion in virus entry: the influenza hemagglutinin. Annu Rev Biochem 2000, 69:531-569.

62. Muñoz E, Molina R, Ferrer D: Babesia shortti infection in a common kestrel (Falco tinnunculus) in Catalonia (northeastern Spain). Avian Pathology 1999, 28:207-209.

63. Diniz JA, Silva EO, Lainson R, de Souza W: The fine structure of Garnia gonadati and its association with the host cell. Parasitol Res 2000, 86:971-977.

64. lezhova TA, Valkiunas G, Loiseau C, Smith TB, Sehgal RN: Haemoproteus cyanomitrae sp. nov. (Haemosporida: Haemoproteidae) from a widespread African songbird, the olive sunbird, Cyanomitra olivacea. J Parasitol 2010, 96:137-143.

65. Nagao E, Arie T, Dorward DW, Fairhurst RM, Dvorak JA: The avian malaria parasite Plasmodium gallinaceum causes marked structural changes on the surface of its host erythrocyte. Journal of Structural Biology 2008, 162:460-467.

66. Cook RF, Avery RJ, Dimmock NJ: Infection of chicken erythrocytes with influenza and other viruses. Infect Immun 1979, 25:396-402.

67. Paulman A, McAllister MM: Plasmodium gallinaceum: clinical progression, recovery, and resistance to disease in chickens infected via mosquito bite. Am J Trop Med Hyg 2005, 73:1104-1107.

68. Schall JJ: The ecology of lizard malaria. Parasitol Today 1990, 6:264-269.

69. Schall JJ: Malarial parasites of lizards: diversity and ecology. Adv Parasitol 1996, 37:255-333.

70. Bongfen SE, Laroque A, Berghout J, Gros P: Genetic and genomic analyses of host-pathogen interactions in malaria. Trends Parasitol 2009, 25:417-422.

71. Hernandez LD, Hoffman LR, Wolfsberg TG, White JM: Virus-cell and cell-cell fusion. Annu Rev Cell Dev Biol 1996, 12:627-661.

72. Nelson RA Jr: The immune-adherence phenomenon; an immunologically specific reaction between microorganisms and erythrocytes leading to enhanced phagocytosis. Science 1953, 118:733-737.

73. Passantino L, Altamura M, Cianciotta A, Patruno R, Tafaro A, Jirillo E, Passantino GF: Fish immunology. I. Binding and engulfment of Candida albicans by erythrocytes of rainbow trout (Salmo gairdneri Richardson). Immunopharmacol Immunotoxicol 2002, 24:665-678.
74. Passantino L, Altamura M, Cianciotta A, Jirillo F, Ribaud MR, Jirillo E, Passantino GF: Maturation of fish erythrocytes coincides with changes in their morphology, enhanced ability to interact with Candida albicans and release of cytokine-like factors active upon autologous macrophages. Immunopharmacol Immunotoxicol 2004, 26:573-585.

75. Bishlawy IM: Red blood cells, hemoglobin and the immune system. Med Hypotheses 1999, 53:345-346.

76. Iwanaga S: The molecular basis of innate immunity in the horseshoe crab. Curr Opin Immunol 2002, 14:87-95.

77. Fogaca AC, da Silva PI Jr, Miranda MT, Bianchi AG, Miranda A, Ribolla PE, Daffre S: Antimicrobial activity of a bovine hemoglobin fragment in the tick Boophilus microplus. J Biol Chem 1999, 274:25330-25334.

78. Mourant AE, Kopec AC, K D-S: Blood groups and diseases Oxford: Oxford University Press; 1978.

79. Rodriguez MF, Wiens GD, Purcell MK, Palti Y: Characterization of Toll-like receptor 3 gene in rainbow trout (Oncorhynchus mykiss). Immunogenetics 2005, 57:510-519.

80. Morera D, Roher N, Ribas L, Balasch J, Doñate C, Callol A, Boltaña S, Roberts S, Goetz G, Goetz F, MacKenzie S: Nucleated erythrocytes can play more than one tune. PLoS One.

81. Robertsen B: The interferon system of teleost fish. Fish Shellfish Immunol 2006, 20:172-191.

82. Bonjardim CA, Ferreira PC, Kroon EG: Interferons: signaling, antiviral and viral evasion. Immunol Lett 2009, 122:1-11.

83. Low TY, Seow TK, Chung MC: Separation of human erythrocyte membrane associated proteins with one-dimensional and twodimensional gel electrophoresis followed by identification with matrixassisted laser desorption/ionization-time of flight mass spectrometry. Proteomics 2002, 2:1229-1239.

84. Kakhniashvili DG, Bulla LA Jr, Goodman SR: The human erythrocyte proteome: analysis by ion trap mass spectrometry. Mol Cell Proteomics 2004, 3:501-509.

85. Tyan YC, Jong SB, Liao JD, Liao PC, Yang MH, Liu CY, Klauser R, Himmelhaus M, Grunze M: Proteomic profiling of erythrocyte proteins by proteolytic digestion chip and identification using two-dimensional electrospray ionization tandem mass spectrometry. J Proteome Res 2005, 4:748-757.

86. D'Alessandro A, Righetti PG, Zolla L: The red blood cell proteome and interactome: an update. J Proteome Res 2010, 9:144-163.

87. Kabanova S, Kleinbongard P, Volkmer J, Andree B, Kelm M, Jax TW: Gene expression analysis of human red blood cells. Int J Med Sci 2009, 6:156-159.

88. Lewis JM, Hori TS, Rise ML, Walsh PJ, Currie S: Transcriptome responses to heat stress in the nucleated red blood cells of the rainbow trout (Oncorhynchus mykiss). Physiol Genomics 2010, 42(3):361-73.

doi:10.1186/1297-9716-42-89

Cite this article as: Morera and MacKenzie: Is there a direct role for erythrocytes in the immune response? Veterinary Research 2011 42:89.

\section{Submit your next manuscript to BioMed Central and take full advantage of:}

- Convenient online submission

- Thorough peer review

- No space constraints or color figure charges

- Immediate publication on acceptance

- Inclusion in PubMed, CAS, Scopus and Google Scholar

- Research which is freely available for redistribution

Submit your manuscript at www.biomedcentral.com/submit
C Biomed Central 